\title{
AN OUTLINE OF GREEK CATHOLIC MONASTICISM IN THE CZECH LANDS AND CZECHOSLOVAKIA THROUGHOUT THE 19TH AND 20TH CENTURY
}

\author{
Jakub Zouhar
}

God Is Love, Let's Love Him.

Bishopric Motto of Pavol Gojdič, OSBM

DOI: 10.17846/CL.2018.11.2.151-167

\begin{abstract}
ZOUHAR, Jakub. An Outline of Greek Catholic Monasticism in the Czech Lands and Czechoslovakia throughout the 19th and 20th Century. Byzantine-rite Christians have always been of little importance to general public living in Czechoslovakia, especially to inhabitants of Bohemia. Moreover, Slovak elites did not always choose an even-handed approach to the Greek Catholic Church. This was caused by the different character of Byzantine-rite Christians, very often Rusyns by origin. That was why the history of Byzantine-rite Christians was so complicated within the defined territory throughout the 19th and 20th centuries. It is even truer of Greek Catholic monasticism. Those who decided to be an enemy of the Greek Catholics had to start with the elimination of their elite - monks and nuns. The worst time for Byzantine-rite Christians came in the second half of the 20th century when the states where they lived were ruled by Communists regimes.
\end{abstract}

Keywords: Greek Catholicism, Monasticism, Bohemia, Moravia, Hungary, Czech Republic, Slovak Republic, Czechoslovakia, Ukraine, the Rusyns, 19th Century, 20th Century

\begin{abstract}
Abstrakt: Zouhar, Jakub. Prehlad gréckokatolíckeho monasticizmu v Česku a Československu počas 19. a 20. storočia. Krestania byzantského obradu nikdy nemali pre širokú verejnost’ žijúcu v Československu, predovšetkým pre obyvatelov Čiech, velký význam. Ani slovenské elity nepristupovali vždy ku gréckokatolíckej cirkvi nestranne. Bolo to spôsobené odlišným charakterom krestanov byzantského obradu, velmi často pôvodom Rusínov. Z toho dôvodu bola história krestanov byzantského obradu v rámci definovaného územia počas 19 . a 20. storočia pomerne zložitá. Toto tvrdenie sa vztahuje aj na gréckokatolícke mniśstvo. Kto sa rozhodol byt nepriatelom gréckokatolíkov, musel začat likvidáciou ich elity - mníchov a mníšok. Najhoršie obdobie pre krestanov byzantského obradu nastalo v druhej polovici 20. storočia, ked’v štátoch, v ktorých žili, vládli komunistické režimy.
\end{abstract}

Klúčové slová: gréckokatolíci, mnišstvo, Čechy, Morava, Madarsko, Česká republika, Slovenská republika, Československo, Ukrajina, Rusíni, 19. storočie, 20. storočie

\section{Introduction}

Scattered geographically from the present-day Ukraine to the current Czech Republic, the members of the Greek Catholic Church living in Eastern Europe were connected intellectually by their shared passion for their faith. They had, however, no cohesive organization. In fact, there were several branches within the Church. That is one of the reasons why it is not easy 
to describe the life of these people who were forced to vindicate their attitudes for such a long time. Eastern (Byzantine)-rite Catholics were often overlooked in number and importance, not only by Orthodox believers but also by Roman Catholic Christians even though both groups are in communion with the Bishop of Rome.

In the following paragraphs, we will be able to examine only a very complicated situation. Despite having published more studies on the topic, it soon became clear that to describe it comprehensively is an exceptionally demanding task. Each historian who attempts to write about the Greek Catholic Church in the territory of former Czechoslovakia has to cope with a lack of sources, especially those related to the period prior 19th century. Nonetheless, several treatises on the subject have already been published; some of them served as sources for compiling this text.

At the very beginning of the chapter it is necessary to say a few words in order to introduce the territorial integrity of the region which covers several states today. These states - Czech Republic, Slovak Republic, Poland, Hungary and Ukraine - have always been completely different from each other in terms of geography, culture, as well as history and language. Greek Catholics, therefore, have never lived in the same way of life within the territory and they have been spread out over it very unevenly. Most of them have been living in the eastern parts of the region, in the present-day Eastern Slovakia and in the most western part of Ukraine, called Carpathian Ruthenia (also Carpatho-Ukraine, or Zakarpattia). Czechoslovakia, as one of the new states formed after the World War I, consisted of four main districts at the time: Bohemia, MoraviaSilesia, Slovakia, and Carpathian Ruthenia which were regarded, from the standpoint of political geography, as one entire territory. In fact, these districts differed from one another to a significant extent. Greek Catholics, mostly living in eastern regions of Czechoslovakia, came from a poor background because the eastern part of Czechoslovakia suffered from a shortage of skilled staff from time immemorial. In spite of all political coup détats, this fact never changed during the 20th century.

\section{Greek Catholics in the Defined Territory in Outline ${ }^{1}$}

After the disintegration of the Great Moravian Empire two successor states emerged in 907: Hungary and the Czech lands (also known as the Bohemian Kingdom in the Middle Ages, or the Lands of the Czech Crown). They consisted of several historical countries: Bohemia, Moravia, Silesia (until 1742; today mostly incorporated into Poland; the smaller part belonging to Czech Republic is called Czech Silesia today), and Lusatia (under the rule of Bohemian kings till 1635; today in Germany). To further complicate the issue, the Czech lands together with Hungary became part of the Habsburg Monarchy (or Habsburg Empire) from 1526 to 1918. However, the Eastern rite was important in Hungary since there were many Greek monasteries, though it was gradually superseded by the Western rite. In 1504, the church was divided into Western Catholic and Eastern Orthodox denominations. The Cyrillo-Methodian tradition ${ }^{2}$ was still maintained

1 Data used for writing these paragraphs were taken from: Šturák 1999; Hric - Šturák 1998; Vladimirus de juxta Hornad [= pseudonym] 2004; Coranič 2013a; Sládek 2013; Řeckokatolická církev v Česku. 2018. Řeckokatolická církev v Česku [The Greek Catholic Church in the Czech Republic], Wikipedia. February 6, 2018. https://cs.wikipedia.org/wiki/\%C5\%98eckokatolick\%C3\%A1_c\%C3\%ADrkev_v_\%C4\%8Cesku; Gréckokatolícka cirkev na Slovensku. 2018. Gréckokatolícka cirkev na Slovensku [The Greek Catholic Church in the Slovak Republic], Wikipedia. February 6, 2018. https://sk.wikipedia.org/w/index.php?title $=$ Gr\%C3\%A9ckokatol\%C3\%ADcka_cirkev_na_Slovensku\&direction=next\&oldid=4850122.

2 Historical identity of the Greek Catholic Church in Slovakia is built on the conviction that the Eastern Church, using the Church Slavonic as liturgical language, originated in and existed since the time 
in Eastern Slovakia and there is much evidence of this in Spiš. Through the late 13th and 14th centuries, shepherds and Russian people were moving to Slovakia. In 1393, Teodor Koriatovič came to Mukachevo (which was incorporated with the Carpathian Ruthenia into Czechoslovakia in 1919) with a group of new settlers. They founded over three hundred settlements which followed the Eastern rite, reviving the Cyrillo-Methodian tradition and slowing down the process of latinization.

It is believed that a monastery existed in Mukachevo at the beginning of the 11th century. From 1491 onwards, there is a definite pro of that bishops of the Eastern rite had settled there. The priests of this denomination did not have all the privileges and higher functions that a blessing by Latin bishops conferred. After the Reformation, Mukachevo bishops, owing to unfavourable circumstances, lost nearly all their privileges and the monastery was destroyed. Religious chaos also resulted from the spreading of orthodoxy from the east. Hungarian sovereigns tried to solve this by getting the Eastern Christians into a unification process. The Uzhgorod Union, the solemn declaration of 63 bishops, was concluded on April 24, 1646, in the castle chapel of Drugeths in Uzhgorod (also two Basilian monks - Peter Parthéna Petrovič and Gabriel Kosovický - were present) (Šturák 1999, 16). Gradually it gained acceptance over the whole area and by 1661 there were more than five hundred priests united with Rome. The diocese of Mukachevo still functioned as the centre of Hungarian Greek Catholics. Pope Clement XIV issued the Bull Eximia Regalium Principum at Empress Maria Therése's instigation, which established the independent diocese of Mukachevo on September 19, 1771. On July 27, 1787, this was divided into three vicariates: Marmoros, Satmár and Košice. On November 3, 1815, the diocese of Prešov was created from the former Košice vicariate by Emperor Francis I without the recognition of Rome. At its outset, it had 194 parishes and almost 150,000 followers. The emperor nominated Gregor Tarkovič as the head of the diocese. The canonical foundation of the diocese was announced by Pope Pius VII with the Bull Relata semper of September 22, 1818, which also contained regulations governing its activities and specified the powers of the new diocese. After many problems the newly designated bishop, Gregor Tarkovič, took over the leadership of the diocese on November 17, 1818, and it gradually began to develop its activity.

Bishop Josef Gaganec continued the hard work of building and developing the diocese of Prešov. The cathedral was rebuilt and about 24 new brick cathedrals were built too. When serfdom was abolished in 1848, the life of Greek Catholic believers was difficult. They had to resist Magyarisation and latinization of their rite. From 1913 onwards, Stefan Novák was the new head of the diocese (Coranič 2013c). He yielded to the pressure of Magyarisation and introduced Hungarian into church schools as well as into church ceremonies. For this reason, he left for Hungary just after the fall

of the mission of SS. Cyril and Methodius. Moreover, it follows the Cyrillo-Methodian model of church organization. There are 3 basic characteristics of this model: eastern spirituality, liturgy in a language close to the spoken idiom, and the unity with the Papal See in Rome. The model of the church has always been viable in the territory, despite its marginalization in the Middle Ages. It is also believed that the existence of the Greek Catholic Church in the territory of the former Kingdom of Hungary is not an exclusive product of the Union with Rome concluded in 1646. The origins of this ecclesiastical community cannot therefore be schismatic. However, the religious identity of the Orthodox Church in Slovakia is equally and firmly built upon the tradition of direct organization from SS. Cyril and Methodius. Generally speaking, the Greek Catholic Church historiography tends to undermine the importance of the Union of Uzhgorod. The Union is interpreted as a formal establishment, legal confirmation of the existence of the Greek Catholic Church in the north-eastern territories of the Kingdom of Hungary that represented a certain line of separation between the East and the West. The historiography also emphasizes the aspect of the voluntary accession to the Union. For general context see (Šoltés 2010, 35-48; Lichner - Marinčák Žeňuch 2013). 
of the Austrian-Hungarian Empire and leadership was taken over by Mikuláš Russnák. At the time, the new border separated 21 parishes from the diocese of Prešov which became Hungarian, but the parishes which were now in Czechoslovak territory remained under the administration of the diocese of Mukachevo with its residence in Uzhgorod. In 1918 - 1926, Greek Catholic Church went through a very hard and complicated period. The unflattering economic situation after the World War I, the division of clergy into several national branches, and Magyarisation in the Slovak territory were the most serious problems. There was Modus Vivendi of 1928, an agreement between Vatican and Czechoslovakia, which regulated the complex relationship between the churches and the Czechoslovak state. Bishop Dionýz Mjárady was succeeded in 1927 by Bishop Pavol Gojdič (1888 - 1960 in a Communist prison) in 1927, a Basilian and a man of unusual qualities and a saintly life. During his leadership the diocese showed a many-sided development; however, this was violently interrupted by the political changes after the World War II. On December 16, 1933, the main parish of St Clement in Prague was established for all Greek Catholics from Bohemia, Moravia and Czech Silesia. Bishop Gojdič later created a parish in Brno for Moravians and Silesians. Moreover, the ecclesiastical administrations of the Greek Catholic Church arose in the Bohemian and Moravian towns of Liberec, Tachov, Plané, Jelení, Mikulov and Bruntál shortly after 1945.

Since the renewed Czechoslovakia was in the sphere of influence of the Soviet Union, the Communists quickly took power in the state in 1948 and decided to liquidate the Greek Catholic Church as such. At the time the church in Czechoslovakia numbered 345 clergymen (including 27 Basilians, 29 Redemptorists, 28 Basilian nuns, and 72 Sisters Servants of Mary Immaculate) (Šturák 1999, 64), 242 parish offices, 11 towns with chaplains, 241 parish churches, 171 local churches, 49 chapels and 305,600 believers (in the territory of the present-day Czech Republic there were 2 parish offices with 11 local churches and 68,400 believers). Having staged a large Convocation in Prešov, the Communists abolished the Union with the Catholic Church and instituted a manifest joining of the Greek Catholics to the Orthodox Church. Many priests including the bishops were interned in prison and the church property was transferred to the Orthodox Church. The rest of clergy were forced to move to Bohemia where they were subjected to forced labor. Most of the congregations retained their religion during these most difficult times. Following the democratic changes in 1968, the Greek Catholics also applied for their rights. Priests were able to return home. By a government decree of May 29, 1968, former property was restored to the Greek Catholic Church and a further resolution of June 13,1968, gave them the same rights as other churches. The schools were restored together with the orders and religious life. On December 20, 1968, Pope Paul VI nominated Ján Hirka as the ordinary for the Greek Catholic Church with the rights of a bishop. Nonetheless, this time period did not last long. After the military invasion in August 1968, Czechoslovakia returned to Communist totalitarianism. This marked a new period of oppression for the churches. Despite this fact the Greek Catholic Church, owing mainly to its work with young people, was developing within.

A new stage of development for the Church started after the fall of Communist dictatorship in 1989. Following a government resolution of May 29, 1990, the ownership rights for church property, removed in 1950, were restored. There was a renewal of religious life. After the division of Czechoslovakia in 1993, a diocesan vicariate was organized in Prague. Ivan Ljavinec was appointed as the new Episcopal vicar there. Pope John Paul II established a new apostolic Exarchate under the leadership of Ivan Ljavinec in the Czech Republic on March 13, 1996. In 2003 he was succeeded by Ladislav Hučko. On February 25, 1997, the archdiocese of Košice was established. Pope Benedict XVI raised this to the level of an Eparchy on January 30, 2008, and at the same time erected the new Byzantine-rite Eparchy of Bratislava. He also raised Prešov to the level of a Metropolitan See, constituting the Slovak Greek Catholic Church as a sui iuris metropolitan 
Church. Nowadays the Archeparchy of Prešov has two suffragans: Eparchy of Bratislava and Eparchy of Košice. In their liturgy, Greek Catholics in Slovak Republic use mainly Slovak, partly also Old Slavonic language, Ruthenian and Hungarian, rarely Old Greek.

However, according to the 2011 census there were 9,927 Greek Catholic followers in the Czech Republic; several thousand believers, mainly from Slovakia and Ukraine who temporally work in the country, should also be included. For that reason, there were 25 parishes with 35 priests for 177,704 faithful in the Czech Republic in 2007.

In addition to secular priests, several orders have operated in the defined territory throughout history. However, they never operated with the same intensity there and their stories are different as well. Although the orders, namely Basilian Order of St. Josaphat, Sisters of St. Basil the Great, the Congregation of the Most Holy Redeemer, and the Sisters Servants of Mary Immaculate, are of great importance to the church since each priest had to partake in the spiritual exercises in Ružumberok (Jesuits), Michalovce (Redemptorists), or in Trebišov (Basilians) every three years (Šturák 1999, 70-71). Their social standing outside of the church has always been rather insignificant, particularly in the territory of the present-day Czech Republic. Despite the fact, the Communist regime was scared of these orders because they represented an insuperable obstacle in the path of total destruction of the Geek Catholic Church in Czechoslovakia. For that reason, the orders had to be decimated first. They were usually accused of being involved in a conspiracy against the regime, very often with the assistance of the Organization of Ukrainian Nationalists.

\section{Basilian Order of St. Josaphat (Ordo S. Basilii Magni; OSBM)}

There are five branches of the order of St. Basil the Great, which can be ranked among the oldest religious orders in the world (Magocsi - Pop 2005, 32-33; Vojnar 2003, 142-144). One of them is the Basilian Order of St. Josaphat. It is this branch precisely that pertains to the most widespread religious order of the Greek Catholic Church within the defined territory.

Its origin dates back to 1072 when the rule of St. Basil the Great was introduced in the Pechersk Lavra monastery in Kiev, the capital of Ukraine, by St Theodosius (d. 1074). Subsequently, the rule became the model for other monasteries in Ukraine, Belarus, and Russia. The year 1739, when the Congregation of the Protection of the Holy Virgin (also called the Ruthenian Congregation) was formed, is regarded as the key landmark in the history of the order in the defined territory. Four years later, two provinces (Lithuanian and Ruthenian) were created in the general chapter of Dubno. In 1780, the order was divided into four provinces due to the partition of Poland (1772). After their novitiate and religious profession, young clerical students usually pursued philosophical studies at the monastery of Zhytrovytsi. For theology, they went to Western Europe where Urban VIII had established 22 scholarships for them in the pontifical schools of the following cities: 4 in Rome, 2 in Vienna, 2 in Prague, 2 in Olomouc in Moravia, 6 in Braunsberg in Prussia, and 6 in Graz. Basilians played a key role within the Greek Catholic Church throughout the 17th and 18th centuries. All the metropolitans of Kiev, for instance, were of their order at that time. The members of the order also included such personalities as Ioann Jozif Hodemarský († 1716), the bishop of Mukachevo, the linguist and theologian Arsenij Kocak (1737 - 1800) (Magocsi - Pop 2005, 251), or Michael Molčan (1832 - 1872) (Magocsi - Pop 2005, 331) who fought as a member of the order against the nullification of autonomy of the eparchies of Mukachevo and Prešov in relationship to the Vatican at the Catholic Congress in Budapest in $1869-1871$.

Provinces were ruled by protohegumeni (provincials); monasteries, by either archimandrites appointed for life, or by hegumeni (local superiors) in office for four years. Basilians focus predominantly on education of the youth, missions, and exertions. 
There is a solid evidence about the existence of old monasteries in Krásny Brod (Timkovič 2009) ${ }^{3}$ (originated in the 16th century; Basilians lived there until 1915) and in Bukova Hôrka near Stropkov (Timkovič 2004) ${ }^{4}$ (originated in the 18th century; monks lived there until 1915) (Székely - Mesároš 1997, 53). Both of them were located within the present-day Slovak Republic. The most important monastery, however, was located outside of Slovakia, on Chernecha Hora (monk's hill) in Mukachevo. The monastery of the origin, dated back to the 11th century, joined the Basilian Order after the Union of Uzhgorod in 1646. In 1862, most of its premises was again destroyed by fire, but rebuilt within three years. Afterwards it ran a school and a library which became important to the cultural and religious life of the region. In the 1920s, the monastery was restructured and reforms were introduced by Basilian monks from Galicia. ${ }^{5}$ In 1946, the Soviet regime liquidated the Ukrainian Greek Catholic Church, and the monastery was forced to become Orthodox.

In the second half of the 19th century the Basilians living in the territory of the presentday Ukraine and Slovakia were faced with a serious identity and economic crisis which had originated in the $1780 \mathrm{~s}^{6}{ }^{6}$ Several monasteries were forcibly closed and there was also a decrease in the number of monks from 75 in the Carpatho-Rusyn province in 1805 to around 20 at the end of the 19th century). A reform, therefore, was necessary. In 1882, Pope Leo XIII ordered that the Jesuits introduce a reform of the Basilian Order. The Jesuit-inspired reform was not introduced into the Carpatho-Rusyn province until 1921. Having been undertaken at the eparchial synod in 1903, the fundamental reform was not greeted with universal acceptance: 11 of the 21 monks refused to accept the changes and either left the order or emigrated abroad. The Carpatho-Rusyn province, like the Galician one, was placed under the direct jurisdiction of the pope at that time. One of the reformed monks was Pavol Gojdič who later, as a bishop of Prešov, was in charge of the reformed Basilians. The future looked bright. There were two provinces in Central Europe: Galicia (covering Poland and the present-day western Ukraine and Belarus), and Carpathian Ruthenia (including Czechoslovakia, Hungary, Romania, and former Yugoslavia). The latter had 163 members, of whom 100 were in Czechoslovakia in the 1930s. Nonetheless, Hungary occupied the Carpathian Ruthenia on March 5, 1939, and all monks of non-Hungarian origin were forced to emigrate. Most of them went to Slovakia where they were under Gojdičs protection. He entrusted them with the care of the parish in Medzilaborce on June 4, 1939. From there, the Basilians organized pilgrimages to the ruins of former monasteries in Krásny Brod and Bukova Hôrka. After overcoming the difficulties which had arisen, they founded new residences in Bukova Hôrka (1942) and in Trebišov (1944; in 1947 an ordinary monastery was founded there). From 1943 onwards, the Basilians administrated a residential college for Greek Catholic teachers in Prešov.

3 According to tradition, the monastery was funded by the Count Laborec in the 9th century and later refunded by the Count Teodor Koriatovich (d. 1414). From the end of the $18^{\text {th }}$ to the early 19 th century, it flourished as the Basilian Philosophical-Theological University. In its glorious past it was destroyed four times: at the beginning of the 14th century, in 1603, 1708, and 1915. Lastly it was rebuilt in 1999 2001, but not in its original place (to preserve old historical ruins) but 50 meters beside it. Now this new Basilian monastery has 20 rooms for monks. Today four Basilian hieromonks live there: V. J. Sedláček, M. M. Bilančík, J. Š. Lucák and P. P. Hal'ko.

4 The history of the monastery prior to the 18th century is unknown. In 1742, the rich pious count Tom Szirmay de Szirma repeatedly provided the monastery with property. In $1771-1796$, the construction of the stone buildings, including a tower, was completed. During the World War I, the monastery was completely destroyed (in 1915 the last monk left the Bukova Hora; the ro of burnt down). In 1942, a small monastery was established. The building was made of clay rolls.

5 A historical region in Central Europe that currently straddles the border between Poland and Ukraine.

6 For general context, see Beales, Derek 1987, 2009. Joseph II, 2 Vols. Cambridge. 
In 1945, the monks of Trebišov, where the Slovak headquarter of the order was, went to Prague to secure the pastoral care there. In 1947 they opened a new monastery including a novitiate in Prešov. In the same year, a new Hungarian independent province was formed. One year later, the then General delegation of Czechoslovakia was upgraded to the independent province of SS. Cyril and Methodius. Šebestian S. Sabol became its first protohegumeni with his residency in Prešov. The new province included three monasteries (Šturák 1999, 73): in Prešov (Fathers: Šebestian S. Sabol, Polykarp P. Bulyk, Nikodém M. Krétt, Marián J. Potáš, Jozef E. Homičko,7 Teodoz T. Čovban, Jozef M. Lojzak, Juraj Bakajsa, Peter Varjan, Andrej Štefko, Štefan Danko, Anton M. Kocak), in Trebišov (Fathers: Polykarp G. Olear, Marián J. Sučko, Ján M. Magur, Simeon Š. Kuzmiak, Emil J. Petro), in Krásny Brod (Jozafát Š. Kuzmiak, Hieronym A. Fedoroňko, Pankrác P. Hučko, Jozafát J. Kaminský, Metod M. Švajka), and there was also a parish in Prague (Nikodém M. Krétt, Emanuel M. Hlavač, Inocent J. Fedoroňko, Hilar J. Benedik, Jozafat J. Breza). In 1950, there were 25 Basilians (including 15 priests) in Czechoslovakia (Šturák 1999, 74).

After the Communist coup of February 1948 times were bleak. Basilians can be ranked among the main objectors to the constrained orthodoxy. Pankrác P. Hučko, who was a parish priest in Prague, was given a 15-year sentence on the basis of false charge as early as December 1948 (but he had spent 21 months in custody before). The Communists also immediately sentenced Šebestian S. Sabol as a protohegumeni to life imprisonment. Fortunately, he had managed to escape through Austria to Rome, and later to the USA. However, another destruction of the order was on its way. The secret police also employed an agent provocateur Jozafát Torbyč, a former monk. Meanwhile, the Slovak Basilians were promoted to a new independent province on March 4, 1948. However, on July 19, 1948, the police raided all Greek Catholic monasteries in Slovakia. The remonstrance of bishop Gojdič fell flat. On April 22, 1949 (at 11.30 pm), the monastery in Prešov was closed and Fathers Potaš, Homička and 9 novices were imprisoned in Ilava and Košice. The monasteries in Trebišov and in Medzilaborce were closed on April 13/14, 1950, and monks were interned in Podolínce (4 of 5 members from Medzilaborce, and 6 from Trebišov). The Basilians Nikodém Mikuláš Krétt (1912 - 1983) and Marián Ján Potáš (1918 - 2006) were also condemned to imprisonment. The former was already in prison in Slovakia during the existence of a semi-independent, Axis client state of Nazi Germany (1939 - 1945), again in 1948 - 1954 for alleged treason, pardoned, but on November 11, 1954, once again he was given a 3-year sentence (Vaško 2007, 59). The latter was arrested by the police many times in 1948 - 1950, eventually was condemned to 10 years for treason, in 1954 released on parole, but in 1958 again condemned to 8 years. Eventually, he was released in 1960 (Vaško 2007, 60).

This destruction of the church in Czechoslovakia was no surprise with respect to the destruction of the Greek Catholic Church in Western Ukraine (1946), Rumania (1948) and Carpathian Ruthenia (1949) (Šturák 1999, 53). ${ }^{8}$

The restoration of the monasteries of the Basilian Order of St. Josaphat in Czechoslovakia took place after 1990. There are three monasteries in the Slovak Republic nowadays: in Prešov (the seat of the Province), in Krásny Brod (the novitiate), and in Trebišov. There is also a monastery in Kula (Serbia) which is included in the Slovak province. ${ }^{9}$ In the Czech Republic, there is no Basilian monastery at present.

\footnotetext{
He held the function of the judge of the primae instantiae in 1948, as well as the position of Professor at the Theological faculty in Prešov (Šturák 1999, 60-61).

8 Two monasteries in Carpathian Ruthenia were re-established after 1991 (Malyi Bereznyi and Imstychovo).

9 http://baziliani.net/node/10 [February 6, 2018].
} 


\section{Sisters of St. Basil the Great (OSBM)}

Founded in the 4th century by St. Basil the Great and his sister, St. Macrina, the community of women is dedicated to the spiritual and educational pursuits of the people of God. The order has its foundations in Europe, North and South America, and Australia and serves primarily people of the Greek Catholic Church. By the 11th century it became centered in Ukraine (Vojnar 2003, 144-145).

Having accepted the invitation from the General Vicar of the Prešov Eparchy Mikuláš Russnák, the sisters came to Czechoslovakia on August 25, 1922 (Čepová 2013). They all came from the town St. Stanislav in Galicia and settled in Prešov where they took up a hall of residence for Greek Catholic schoolgirls (numbering 40 girls). By 1938/39, the sisters worked as teachers at a Greek Catholic school in Medzilaborce. On September 19, 1945, they began to work at an elementary school and nursery in Sečovce (sister Paulína Vasilková taught Maths and Physics, Jozafáta Hámorská History, Russian and Slovak, and Pachomia Petríková worked at the nursery); then, working at an orphanage for children who had lost their parents during the World War II, they established their convents in Svidník and Stropkov. Until 1950, there were 82 sisters living in six centers within the Prešov Eparchy under the Mather Superior Magdaléna Humenjuková: ${ }^{10}$ Prešov (Gertúda Karcubová - the Superior; Agnesa Zenknérová - the Master of Novices; sisters Mária Javorská, Severína Machniková, Parténia Lazoríková, Gerarda Ivančová, and Antónia Horvátová; novices Helena Želizňaková, Anna Vošková, Alžbeta Džuková, Mária Vašutová, Anna Baraníková, Helena Sakalová, and Mária Fečová, and candidates Zuzana Hratová and Alžběta Zvodzová), Medzilaborce (Marciana Horvátová and Teodora Geletejová), Stropkov (Agnesa Halmajová, Naděžda Vašutová, and Helena Solodková), Sečovce (Paulína Vasil'ková, Pachomia Petríková, and Jozafata Hámorská), Svidník (Melánia Bucmanjuková, Jeremija Pankuličová and Metodia Lauruková), and Teplá (Irenea Olexiuková, Bazilia Sivčová, and Imelda Javorská).

From 1948 onwards, the sisters were ceaselessly persecuted for the support of refugees from the USSR. Their convents were raided by the police forces on July 19, 1948, and also during August and September. However, the biggest police assault against them was carried out in Prešov at night on February 22/23, 1949, when six sisters (M. Javorská, I. Javorská, I. Olexiuková, A. Zenknérová, A. Horvátová, and Nadežda Huňovská) were arrested. These sisters, then, had to work in a labor camp in Nováky. The rest of them were forced to leave their convents in September 1949 and were in hiding inside the residence of the Prešov bishop P. P. Gojdič OSBM. In March 1950 they eventually had to leave Prešov for Trenčín, where they were able to work at a hospital thanks to the Vincentian sisters. Elderly or ill sisters were isolated in hospitals. After August 31, 1950, the sisters, who were capable of working, were sent to a detention monastery in Kostolná near Trenčín. Finally, on October 11, 1951, the sisters under 45 years of age were transported to Northern Bohemia (Krásná Lípa, Meziměstí near Broumov, Rumburk, and Wansdorf) whence German-speaking inhabitants had had to leave (Coranič 2009, 93-94). In 1954 - 1989, the sisters were forced to work in a lunatic asylum in Svitavy. Owing to the Prague Spring, a period of political liberalization in Czechoslovakia in 1968, the order was able to accept several novices. Their number doubled. On that account, they were divided into two groups. The first one numbering 6 sisters left for Smilkov near Benešov in 1974 in order to take care of the elderly. In 1986, they moved to Mukařov near Prague where they should spend the rest of their life. The second group numbering 8 sisters carried on working in Svitavy and was consistently humiliated by the regime. They could not return to Slovakia until 1990.

10 As of 1948 (Šturák 1999, 75). 
On May 30, 1990, the sisters moved from Mukařov near Prague to Trebišov in Eastern Slovakia and began to work among believers immediately. The sisters from Svitavy left for Sečovce on January 20 to June 6, 1991. The valuable help came from the sisters living in the USA at that time. On May 8, 1994, the new representation of the order was established in Sečovce. It was promoted to the Vice Province of SS Cyril and Methodius on January 30, 2001. In 1998, there were 39 sisters (also 9 novices and 3 candidates) of Rusyn and Ukraine origin in the Slovak Republic living in the Province of Our Lady of Sorrows (P. Marie Sedmibolestné), and 21 (including 2 novices) of Slovak origin living in the Vice Province of SS Cyril and Methodius with their center in Sečovce (Babjak 1998, 30-38). Nowadays, there are four centers in the Slovak Republic: in Sečovce (the seat of Vice Province), Bratislava, Trebišov, and Vranov nad Toplou. The sisters teach religion in public as well as church schools (Prešov, Trebišov), sew liturgical cassocks, and help in parishes. The order does not operate in the Czech Republic.

\section{The Congregation of the Most Holy Redeemer (Congregatio Sanctissimi Redemptoris; C.Ss.R) - Eastern (Byzantine) Rite}

Members of the Congregation, Catholic priests and consecrated religious brothers, are known as Redemptorists and minister in more than 77 countries around the world (Curley - Hoegerl 2003, 996-996). The order was founded by St. Alphonsus Liguori at Scala, near Amalfi, in Italy in 1732 for the purpose of laboring among the neglected country people in the neighborhood of Naples. At the request of Alphonsus the Congregation was formed by Pope Benedict XIV in 1749 . The Redemptorists focus on theological scholarship too. According to its rite, there are four branches of the order: western, eastern (Byzantine), Syro-Malabar, and Chaldean rite. The Redemptorists of the Eastern rite were formed in Canada at the turn of the 19th century when the Belgian brothers worked among Ukraine emigrants there. The first Redemptorist of the Eastern rite was P. Achiel Deleare (1868 - 1939) who accepted this rite on August 11, 1906. In 1913, the Ukraine Greek Catholic Vice-Province for Canada and Ukraine was established.

The Czech Redemptorists of the Western rite, specifically Metoděj Dominik Trčka (1886 1959) (Mandzák, 2006) ${ }^{11}$ and Mikuláš Nekula (1887 - 1969), came to Slovakia in October 1921. They settled in a desolate Franciscan monastery located in Stropkov. They changed the Western rite to the Eastern one with the permission of their superiors. In 1931, the brothers opened a new monastery for Eastern-rite Redemptorists in Michalovce. On September 17, the monastery was consecrated by protohegumeni of Galician Redemptorists Jozef Schrijvers (1876 - 1945). The monastery has functioned as a new missionary center for eastern Slovakia and the Ukraine. In 1935, when the Redemptorist communities of the area were re-organized, M. Trčka was appointed as Vice Provincial of the Greek Catholic Redemptorists. In 1938 to 1945 the Redemptorists were under threat because of their nationality - most of them were Czech by origin. They were forced to leave the monastery in Stropkov in 1942; only the Western-rite Redemptorists stayed there. There was an air-raid shelter in the beerhouse situated in the building of the monastery in Michalovce

11 Born on July 6, 1886, in the small town of Frýdlant nad Ostravicí in the present-day Czech Republic as the seventh and youngest child of Tomáš Trčka and Františka Štěrbová, he entered the order novitiate in Bilsko, Poland, when he was only 17 years old. After making his first profession on August 25, 1904, he returned to Obořiště in his homeland in order to study philosophy and theology. On July 17, 1910, he was ordained by Cardinal Lev Skrbenský to the Presbyterate within the Latin Rite branch of the Catholic Church. After spending some years engaged in the traditional Redemptorist ministry of conducting parish missions, he was sent to serve the Greek Catholics in Galicia in what is now the Banská Bystrica Region of Slovakia. 
in 1944/45. In January 1945 the Soviet army established its infirmary there. The independent Greek Catholic Vice-Province was definitely established on March 23, 1946. The Byzantine-rite Congregation had its monasteries in Michalovce (M. Trčka, protohegumen; brothers Cyril Zakopal, Augustín Kliment, Jozef Fail, Ján Durkan, Štefan Lazor, Mikuláš Durkan, Jozafat Milík, Hilar Suchý, Konštantin Čepa, Alexej Čepa, Teodoz Michael, Bazil Michalič, Cyril Zelenka, and Matúš Košč), in Stropkov (Teofil Čelustka, Vladimír Arvaj, Jozef Cverčko, Nike for Koropčak, and Jozef Onofrej), and in Sabinov (founded during the World War II; Efrém Kozelský, Alexej Fiala, Boris Zis, and Roman Dandar). Moreover, there were also young clergymen Michal Rusnačok, Andrej Prokopovič and Ján Kováč, as well as brothers standing out of these monasteries: Stanislav Nekula and Ján Mastilak. Together there were 38 members of the Byzantine-rite Congregation (including 14 priests, 11 consecrated religious brothers, 3 young clergymen, and 10 novices) in $1950 .{ }^{12}$

The Redemptorists directed the "Holy Rosary" and issued the journal "Missionary" (Misionár). The last issue was published in January 1949.

In the spring of 1948, the Congregation started to be persecuted in Slovakia. On July 19, 1948, the secret police raided the monastery in Michalovce for the first time. The brothers were falsely accused of a membership in the Organization of Ukrainian Nationalists and, on August 22, 1948, the secret police raided the Michalovce monastery again looking for weapons. At the very beginning of 1949, the regime stopped the publication of the journal Missionary. Simultaneously, Father Š. Lazor $(1913$ - 1996) was arrested by the secret police. He spent 3 months under arrest (January 22 to April 23, 1949), but he was finally released and exiled from Eastern Slovakia. Unfortunately, he was later arrested again three times, and thus spent a total of 7 years in different prisons. ${ }^{13}$ On March 8, 1949, two other brothers were convicted. S. N. Nekula was given a 2-month sentence and a fine of 3,000 Czechoslovak Crowns (CZK). V. Jeřábek was given a 4-month sentence and a fine of 7,000 CZK. In 1949, the independent Vice-Province of the Eastern rite was liquidated and subordinated to the Vice-Province of the Western (Roman) rite with the seat in Bratislava. All three monasteries were definitely closed on April 13/14, 1950. In December 1949, Fathers J. C. Zakopal and V. Arvaj (1914 - 1994) were arrested. The former was later released, but the latter was given a 5-year sentence for treason. He spent these years in prison Valtice; in 1954, as a citizen of Yugoslavia, he was transported to the Austrian border (Vaško 2007, 55). On March 14, 1950, Father J. Mastiliak was arrested and stood trial with other nine monks from different orders for treason. ${ }^{14}$ The procurator demanded death penalty; however, the court finally condemned him to life imprisonment and a fine of 50,000 CZK. He spent 16 years in prison. Furthermore, Brother Michal Majovský ( $\left.{ }^{\star} 1923\right)$ was also arrested in 1950. One year later, he had to complete a threeyear military service as a member of "The Auxiliary Technical Battalions" (Pomocné technické prapory) - special forces which should "re-educate" Communist male objectors in the 1950s. ${ }^{15}$

12 As of 1948 (Šturák 1999, 75).

13 For more information, see (Vaško 2007, 50).

14 The first show trial was conducted "against representatives of selected monastic communities named according to Premonstrate Augustin Antonín Machalka, who was one of the accused monks. A group of selected victims consisted of 10 monks from five monastic communities which included the only Slovak, the Greek Catholic Redemptorist J. I. Mastiliak. ... A monster trial was an experiment in a way, because it designated the competence of particular parties to a trial (competence of attorney general, prosecutors, chief justice, assessors, board of auxiliaries). Defendants and witnesses did not memorize judicial reports yet, so that their depositions during the main hearing corresponded to them. They did not agree with everything, but tried to defend themselves. Later on, in the following trials, also this phase of political trials was sophisticated - defendants and witnesses were forced to testify exactly according to the minutes from the investigation." (Mandzák 2008, 361-362; Mandzák 2009).

15 They were first established on September 1, 1950, and lasted for 4 years; all the same, even now, they have 
On May 23, 1953, Majovský was given a 7-month sentence for "illegal activities." Fortunately, he was granted general pardon and was released. Nevertheless, Majovský was arrested again in 1955 and labelled as a religious fanatic because he insisted on his Catholic conviction during the trial. For that reason, he was given a 4-year sentence (Vaško 2007, 48-49). Besides, the Theology student brother Michal Roško ( $\left.{ }^{\star} 1928\right)$ was arrested in 1950, spent 3 years in "The Auxiliary Technical Battalions", and later worked as a X-ray technician in Košice. However, he was given a 2,5-year sentence for his secret theological study in 1962, he was fortunately released the same year due to general amnesty. Ten years later Roško finished his theological studies in Litoměřice (Bohemia) and was ordained as a priest by bishop Hopko (Vaško 2007, 61-62).

The Vice Provincial M. D. Trčka was arrested on the evening of April 13, 1950. He was put on trial and accused of trying to obtain false papers in order to flee the country and was sentenced to 12 years in prison. During his imprisonment, as one of the Church leaders he endured both torture and interrogation. On March 23, 1959, he died as of pneumonia, having been placed in solitary confinement as a punishment for singing Christmas carols. In 1969, his remains were exhumed and placed in the Redemptorist crypt in Michalovce Cemetery. Father Dominick was declared a martyr by Pope John Paul II on April 24, 2001, and beatified by the same pope on November 4, 2001.

Other Eastern-rite Redemptorists were arrested and transported to the detention camp in Podolínec; later, they were transported to different camps of forced labor throughout Czechoslovakia (Coranič 2009, 85-87). For all attempts at restoration of the order in Slovakia in $1968^{16}$, the brothers had to wait until 1990 in order to re-emerge as a public association. Nowadays, Eastern-rite Redemptorists live in Slovak monasteries in Michalovce (the seat of the ViceProvince), Stropkov, and Stará Lubovňa. In 1998, the Vice-Province included 30 members, 3 novices and 9 candidates (Babjak 1998, 186-189). There were also four sisters of the Order of the Eastern rite in Slovak in 1998, but no monastery yet (Babjak 1998, 199).

\section{The Sisters Servants of Mary Immaculate (S.S.M.I.)}

Founded in the hamlet of Žužel' near Lviv in 1892, the religious congregation of women is the first such organization in the Ukrainian Greek Catholic Church. The founders were Blessed Josaphata Hordashevska (1869 - 1919) and Father Jeremiah Lymnytsky OSBM (1860 - 1915). He was among the first members of his Order trained under Polish Jesuit Fathers, who had been ordered by Pope Leo XIII due to their decline over the centuries of persecution. As a result of his experience with Polish Roman Catholics, Lymnytsky conceived the idea of establishing communities of active religious sisters to assist the Basilians in answering the great social needs of the people, as had emerged throughout Western Europe during that era. Within ten years, the 8 Sisters had grown to 128 , living in 26 convents throughout the region of the Ukraine. They were able to hold their first General Chapter in 1902, in the course of which Sister J. Hordashevka was elected the first Superior General of the Congregation. The Sisters Servants had been founded to minister to the spiritual, moral, intellectual and social needs of the Ukrainian people. As many of them

lost little in notoriety. Tens of thousands of men - both young and older, who had been dubbed enemies of the state - were forced to serve, carrying no weapons, suffering hard labor and experiencing constant harassment.

16 The Eastern-rite Redemptorists was eager to go back to Stropkov; however, the buildings were owned by the Orthodox Church which did not want to give up using this property. Finally, the Redemptorists had to wait until 1991. Instead, they built a family house in Stropkov in 1973 which was converted to a new monastery after 1990. 
emigrated to other countries over the years in search of a better life, the Sisters branched out from western Ukraine to Canada, Yugoslavia, Brazil, the USA, Poland, Slovakia, Italy, the UK, France, Argentina, Germany, Australia and Kazakhstan.

The Sisters were invited to Czechoslovakia by bishop Gojdič on September 14, 1928. There were four of them and they settled in Prešov, where they ran an orphanage from 1934. Simultaneously, they took care of poor women and girls whose number had risen in connection with the Great Depression in the 1930s. In 1938, the Congregation got a new house in Michalovce. It was a gift from the Sotáks. On May 6, 1938, the novitiate for the sisters was established by bishop Gojdič in Prešov. Another house was opened in Trebišov in 1940. There was a school and a nursery school under their protection there. The third house in Slovakia was established with the assistance of bishop Gojdič in Lutina in 1942. After the liquidation of the Galician Province in 1947, the new Slovak Vice-Province entitled Holy Spirit was formed. Around 30 Ukrainian sisters left their home for Slovakia at the time (Coranič 2009, 95). In 1948, there were 76 sisters, novices and candidates, as well as these convents in Czechoslovakia (Šturák 1999, 76-77): Prešov (Filareta Fedinová, the Superior of the Province; Melánia Lutašová, the Superior of the convent; Mytrofana Michalecká, the Superior of the Novices; and sisters Jozefína Delkovičová, Andrea Hiščaková, Anna Procivová, Bazilia Kuchariková, Teofilakta Ostiuková, Viera Tutková, Nadežda Gavulová, Elia Erdeková, Lubomíra Pekarová, Šebestiána Musnyková, Eufémia Nováková, Magdaléna Karasová, Nikefora Potocká, Ambrózia Jarošová, Pachomia Sučková, Pankrácia Musnyková, Paraskeva Hiščáková, and Mária Protivňaková; novices Anastázia Pelaková, Juliana Ujhelská, Modesta Diordiová, Olga Špicová, Johanna, Tarzicia and Gerarda Mikitinová, Klementa Turčanová, Ignácia Turčaníková, Makrína Peleščaková, Euzébia Tirpaková, and Michaela Tarčová; and candidates Johana Niariašová, Anna Brozynová, Anna Ištvaníková, and Johana Kundratová), Michalovce (Teonia Blyzniuková, the Superior; sisters Onisima Frajtová, Longina and Jozefa Škovranová, Vladimíra Turčanová, Laurenti and Marta Tarabčaková, and Teodózia Mišová), Lutina (Jeremia, the Superior; sisters Isaia Mitrovková, Eustachia Legnavská, Justína Sidlarová, Cecília and Veronika Zbihlejová Irena Protivňaková, and Natália Ješinková), Trebišov (sisters Krescencia Hodovanská, Christofóra Ondiková, and Jozafata Mal'covská), Libějovice (sisters Dorotea, Eunikia, Augustína, Sofia, Minodora, Juliana, Chleba, and Juraja), and Uherské Hradiště (sisters Tadea Rudková, Gabriela Tatarová, Chryzostoma, Auxentia, Daria, Pavla, Natália, Anastázia, Kristína, Katarína, Minodora, and Simeona).

From 1947 onwards, the sisters were consistently victimized. A year later, the Communist regime in Czechoslovakia started to look for all the Ukrainian and Galician sisters. Most of them left Slovakia for Moravia or Bohemia, but they were promptly arrested and after one year of detention in Ilava prison, they were transported to Poland. On June 8, 1949, the sisters were expelled from the orphanage in Prešov. They had to stay work in different state children's homes, only four sisters were able to work in the bishopric Prešov residence until April 28, 1950. The convent in Libějovice was closed in 1949; the convent in Trebišov on August 30, 1950. The sisters, then, had to work in the Uherské Hradiště hospital. The sisters from Trebišov were transported to the village of Kostelná near Trenčín on August 29, 1950. The Vice-Province Holy Spirit was dissolved on June 3, 1949, and seized its properties, as well as that of all other religious institutions.

Owing to these circumstances, the Superior General of the Congregation Veronika Girgilová asked the Congregation for the Oriental Churches in Rome for some permissions so that the sisters could live secret lives of dedication. The Congregation for the Oriental Churches complied with the supplication on April 22, 1950, and decided that the sisters of the Slovak Vice-Province are able to take novices in any house, these novices are able to choose any sister they like, and their first vow can be taken in front of any priest. Only because of these special rules the Vic- Province was able to operate in Czechoslovakia in the 1950s. After 1956, the sisters of the age of 46 and more 
should work in old people's homes, the younger ones were transported to Northern Bohemia where they worked in textile industry. There, they could live together. Ill sisters or those who were too old spent the rest of their lives in old people's homes.

The Sisters Servants of Mary Immaculate were arrested in Czechoslovakia in the 1950s too. Sister Superior Filareta Fedinová was given a 7-year sentence and Sister Onezima Frajtová was given a 5-year sentence for their relationship with Polish sisters.

With the collapse of the Communist regime in Czechoslovakia in 1989, Sisters who had lived their consecrated lives in secret were able to re-emerge as a public association. Members of the Congregation from all over the world joined together to support and help their Sisters in Eastern Europe. In the Slovak Republic, the Congregation has its houses in Prešov (the seat of the Congregation and novitiate), Košice, Michalovce (they work in an old people's home there), Sobrance, Snina, Humenné, Poprad, Stará Lubovňa, Spišská Nová Ves (they work in a hospital for mentally ill people there), Lutina and Gelnice today. In 1998, the Slovak Congregation numbered 77 sisters and 5 novices (Babjak 1998, 224). There are no monasteries of the order in the Czech Republic.

\section{Conclusion}

Byzantine-rite Christians have always been of little importance to general public living in Czechoslovakia, specifically to inhabitants of Bohemia. This fact has played a key role in a relationship among people within the territory of former Czechoslovakia, whose faith has never been well-proportioned within the defined territory. The political, administrative, business, and cultural center was always in the capital, i.e. in Prague. However, its citizens, including politicians, often adopted a half-hearted approach to the matter of faith. It is even truer in the case of Byzantine-rite Christians. That was one of the reasons for disapproval of a certain number of Slovakians before 1993. On the other hand, the Slovak elites did not always choose an even-handed approach to the Greek Catholic Church. This was caused by the different character of Byzantine-rite Christians, very often Rusyns by origin. A vital part of Slovak society perceived them as foreigners, particularly in the years 1938 to 1945. That was why the history of Byzantine-rite Christians was so complicated within the defined territory throughout the 19th and 20th centuries. And if this holds true for the Greek Catholic Church in general, it is even truer of its monasticism. Those who decided to be an enemy of the Greek Catholics had to start with the elimination of their elite - monks and nuns. Owing to the fact that Rusyns have never had their own state, and some of the governments which have ruled over them have ignored or actively tried to suppress their history and/or culture, the Byzantine-rite priests and even more significantly monks adopted a posture of defense towards their neighbors (Slovaks, Hungarians, Poles, Ukrainians, and partly Czechs) who spoke different languages, and had different culture and partly different history. The worst time for Byzantine-rite Christians came in the second half of the 20th century when the states where they lived were ruled by Communists regimes which even banned the name "Rusyn" and refused to acknowledge that Rusyns comprise a distinct people, or nationality. The Greek Catholic Church, as a symbol of the people, was liquidated in these states without any reference to nationality of its members.

The complicated, possibly woeful history of the Byzantine-rite Christians in Central and Eastern Europe including their elite - Brothers and Sisters who dedicated their life to Lord - is the reason for little general knowledge about Greek Catholic monasticism. Being aware that this account does not exhaust the subject at all, one nevertheless hopes that it will serve as a useful guide for all those 
interested in and in need of information about the rich history of Greek Catholic monasticism in the Czech lands and Czechoslovakia of the 19th and 20th centuries.

\section{REFERENCES}

Adam, Ján. 2010. Historiografia Prešovského biskupstva v prvej polovici 19. stolečia [The Historiography of the Prešov Eparchy in the 1st Half of 19th Century]. In Mačala, Pavol Marek, Pavel - Hanuš, Jiří (ed.). Církve 19. a 20. století ve slovenské a české historiografii. Brno, 49-58.

Babjak, Ján. 1998. Rehole a kongregácie na Slovensku [Orders and Congregations in the Slovak Republic]. Trnava.

Borza, Peter - Mandzák, Atanáz Daniel. 2010. Náboženský život gréckokatolíkov v rokoch 19391945 [Religious Life of the Greek Catholics in Slovakia in 1939 - 1945]. In Sokolovič, Peter (ed.). Život v Slovenskej republike: Slovenská republika 1939 - 1945 očami mladých historikov 9. Bratislava, 326-335.

Borza, Peter. 2012. Ilegálne aktivity Gréckokatolíckej cirkvi v Československu v rokoch 1951 - 1958 [Illegal Activities of the Greek Catholic Church in Czechoslovakia in 1951 - 1958]. In Jašek, Peter (ed.). Protikomunistický odboj v strednej a východnej Európe: zborník z medzinárodnej vedeckej konferencie, Bratislava 14. - 16. novembra 2011. Bratislava, 92-101.

Čepová, Antónia Petra. 2013. Rád sestier sv. Bazila Vel'kého v kontexte 90. výročia príchodu na územie dnešného Slovenska [Sisters of the Order of St. Basil the Great in Context of 90th Anniversary of their Arrival to the Land of the Present-day Slovak Republic]. In Coranič, Jaroslav (ed.). Gréckokatolícka cirkev na Slovensku vo svetle výročí. III. Prešov, 353-366.

Coranič, Jaroslav. 2009. Sonda do procesu likvidácie gréckokatolíckych reholných komunít na Slovensku [A Case Study on the Process of Destruction of the Greek Catholic Orders in Slovakia]. In Weis, Martin et al. Kříž pod rudou hvězdou. České Budějovice, 78-97.

Coranič, Jaroslav. 2013a. Dejiny Gréckokatolíckej cirkvi na Slovensku v rokoch 1918 - 1939

[A History of the Greek Catholic Church in Slovakia in 1918 - 1939]. Prešov.

Coranič, Jaroslav (ed.). 2013b. Gréckokatolícka cirkev na Slovensku vo svetle výročí. III [The Greek Catholic Church in Slovakia in the Light of Anniversaries]. Prešov. Coranič Jaroslav. 2013c. Život a činnost’ prešovského gréckokatolíckeho biskupa Dr. Štefana Nováka (1913 - 1920) [The Life and Work of the Greek Catholic Bishop of Prešov Dr. Stephan Novák (1913 - 1920)]. In Coranič, Jaroslav (ed.). Gréckokatolícka cirkev na Slovensku vo svetle výročí. III. Prešov, 335-351.

Coranič, Jaroslav. 2010. Gréckokatolícka cirkev na Slovensku v rokoch 1918 - 1926 [The Greek Catholic Church in Slovakia in 1918 - 1926]. In Mačala, Pavol - Marek, Pavel - Hanuš, Jiř́ (ed.). Církve 19. a 20. století ve slovenské a české historiografii. Brno, 477-492.

Coranič, Jaroslav. 2014. Z dejín Gréckokatolíckej cirkvi na Slovensku [On the History of the Greek Catholic Church in Slovakia]. České Budějovice.

Curley, M. J.- Hoegerl, C. 2003. Redemptorists. In New Catholic Encyclopedia, 2nd ed., Vol. 11. Detroit, 993-996.

Hanuš, Milan. 2006. (ed.). 10 let Apoštolského exarchátu [10 Years of Apostolic Exarchate]. Praha. Hradil, Jakub. 2008. K dějinám řeckokatolické církve v Čechách a na Moravě ve 20. století

[On the History of the Greek Catholic Church in Bohemia and Moravia in the 20th Century].

Master's thesis, Masaryk's University, the Faculty of Education, Brno.

Hric, Ján - Šturák, Peter. 1998. Prešovské biskupstvo [The Eparchy of Prešov]. Prešov. 
Létz, Róbert. 2000. Postavenie gréckokatolíkov slovenskej národnosti v rokoch 1918-1950 [The Social Standing of the Greek Catholics of the Slovak Nationality in 1918-1950]. In Dorula, Ján (ed.). Slovensko-rusínsko-ukrajinské vzt̉ahy od obrodenia po súčasnost'. Bratislava, 101-118.

Lichner, Miloš - Marinčák, Šimon - Žeňuch, Peter. 2013. Kultúrna identita gréckokatolíkov vo svetle cyrilo-metodského dedičstva I [Cultural Identity of the Greek Catholics in the Light of the Cyril-Method-Heritage]. Bratislava.

Magocsi, Paul Robert - Pop, Ivan (ed.). 2005. Encyclopedia of Rusyn History and Culture. Toronto. Mandzák, Daniel Atanáz 2006. Blahoslavený Metod Dominik Trčka [Bt. M. D. Trčka]. Michalovce. Mandzák, Daniel Atanáz (ed.). 2009. Dokumenty k procesu s Augustinom A. Machalkom a spol [The Critical Edition of Documents on the Trial "A. A. Machalka and Company"]. Bratislava.

Mandzák, Atanáz Daniel. 2010. Akcia „REDE“ - prenasledovanie redemptoristov v rokoch 1961 1962 [The Case "REDE" - Persecution of the Redemptorists in 1961 - 1962]. In Jakubčin, Pavol (ed.). Likvidácia reholí a ich život v ilegalite v rokoch 1950 - 1989: zborník z vedeckej konferencie Bratislava 5. - 6. mája 2010. Bratislava, 81-98.

Mandzák, Atanáz Daniel. 2012. Odpor gréckokatolíckych laikov voči záverom tzv. Prešovského soboru v roku 1950 [The Resistance of the Greek Catholic Laics to Conclusions of PrešovClergy-Meeting of 1950]. In: Jašek, Peter (ed.). Protikomunistický odboj v strednej a východnej Európe: zborník z medzinárodnej vedeckej konferencie, Bratislava 14. - 16. novembra 2011. Bratislava, 118-151.

Mandzák, Daniel Atanáz. 2014. Dokumenty k akcii „P“: prešovský „sobor“ [Documents on the Case "P": The Prešov-Clergy-Meeting]. Bratislava.

Mynárik, Ján. 2005. Osud Banderovců a tragédie řeckokatolické církve [The Destiny of the Members of the Organization of Ukraine Nationalists and the Tragedy of the Greek Catholic Church]. Praha.

Myshchyshyn, Iryna - Tcura, Svitlana. 2014. Contribution of Orders and Institutes of Consecrated Life of Ukrainian Greek-Catholic Church to the Formation of National Consciousness of Ukrainian Children and Youth. In Czech-polish historical and pedagogical journal VI/1, 20-29 http://www.ped.muni.cz/whis/j6o1.pdf.

Potaš, Marián. 1999. Dar lásky: Spomienky na biskupa Pavla Gojdiča, OSBM [Blessing of Love: To the Memory of Bishop Pavol Gojdič, OSBM]. Prešov.

Sládek, Karel et al. 2013. Řeckokatolická církev v českých zemích: dějiny, identita, dialog [The Greek Catholic Church in the Czech Lands: History, Identity, Dialog]. Červený Kostelec.

Šoltés, Peter. 2010. Dědici Cyrila a Metoda alebo Uniati. Problém kontinuity a diskontinuity gréckokatolíckej cirkvi v slovenskej historiografii a kultúrnej pamäti [The Heirs of SS. Cyril and Method or Uniates? The Issue of Continuity and Discontinuity of the Greek Catholic Church as Reflected in the Slovak Historiography and Cultural Memory]. In Mačala, Pavol Marek, Pavel - Hanuš, Jiří (ed.). Církve 19. a 20. století ve slovenské a české historiografii. Brno, 35-48.

Šturák, Peter. 1999. Dejiny Gréckokatolíckej cirkvi v Československu v rokoch 1945 - 1989 [A History of the Greek Catholic Church in Czechoslovakia in 1945 - 1989]. Prešov 1999.

Šturák, Peter. 2010. Gréckokatolicka cirkev v Československu v rokoch 1945 - 1950 [The Greek Catholic Church in Czechoslovakia in 1945 - 1950]. In Mačala, Pavol - Marek, Pavel - Hanuš, Jiří (ed.). Církve 19. a 20. století ve slovenské a české historiografii. Brno, 549-558.

Székely, Gabriel - Mesároš, Anton. 1997. Grékokatolíci na Slovensku [The Greek Catholics in Slovakia]. Košice.

Timkovič, Jozafát Vladimír. 2004. Letopis Bukovského monastyra Bukova Hora [The History of the Monastery in Bukova Hora]. Prešov. 
Timkovič, Jozafát Vladimír. 2009. Dejiny baziliánskeho monastyra v Krásnobrode od 9. storočia po súčasnost' [The History of the Basilian Monastery in Krásny Brod near the Medzilaborce from the 9th Century up to the Present]. Košice.

Vasil,' Cyril. 2000. Gréckokatolícke liturgické knihy a normy - prostriedok jednoty a príležitost’ na konfrontáciu jednotlivých národných a cirkevných spoločenstiev [Greek Catholic Liturgical Books and Regulations]. In Dorula, Ján (ed.). Slovensko-rusínsko-ukrajinské vztahy od obrodenia po súčasnost́. Bratislava, 285-312.

Vaško, Václav. 2007. Likvidace řeckokatolické církve [Destruction of the Greek Catholic Church in Czechoslovakia]. Kostelní Vydří.

Veverková, Kamila. 2009. Pronásledování řeckokatolické církve v Československu po únorovém prrevratu v roce 1948 [Persecution of the Greek Catholic Church in Czechoslovakia after the Communist Coup in February of 1948]. In Weis, Martin et al. (ed.). Kř́ž pod rudou hvězdou. České Budějovice, 110-119.

Vladimirus de juxta Hornad [= pseudonym]. 2004. Dejiny Gréckokatolíkov Podkarpatska (9. - 18. storočie) [History of the Greek Catholic Church in SubCarpathia in the 9th to 18th Centuries]. Košice (a controversial book).

Vojnar, M. M. 2003. Basilians (Byzantine). In New Catholic Encyclopedia, 2nd ed., Vol. 2. Detroit, 142-144.

Řeckokatolická církev v Česku. 2018. Řeckokatolická církev v Česku [The Greek Catholic Church in the Czech Republic], Wikipedia. February 6, 2018. https://cs.wikipedia.org/wiki/\%C5\%98e ckokatolick\%C3\%A1_c\%C3\%ADrkev_v_\%C4\%8Cesku.

Gréckokatolícka cirkev na Slovensku. 2018. Gréckokatolícka cirkev na Slovensku [The Greek Catholic Church in the Slovak Republic], Wikipedia. February 6, 2018. https://sk.wikipedia. org/w/index.php?title=Gr\%C3\%A9ckokatol\%C3\%ADcka_cirkev_na_Slovensku\&direction= next\&oldid $=4850122$.

\footnotetext{
SUMMARY. AN OUTLINE OF GREEK CATHOLIC MONASTICISM IN THE CZECH LANDS AND CZECHOSLOVAKIA THROUGHOUT THE 19TH AND 20TH CENTURY. Byzantine-rite Christians have always been of little importance to general public living in Czechoslovakia, especially to inhabitants of Bohemia. This fact has played a crucial role in the relationships among people within the territory of former Czechoslovakia, whose religious faith has never been well-proportioned within the defined territory. Those who decided to be an enemy of the Greek Catholics had to start with the elimination of their elite - monks and nuns. Owing to the fact that Rusyns have never had their own state, and some of the governments which have ruled over them have ignored or actively tried to suppress their history and/or culture, the Byzantine-rite priests and even more significantly monks adopted a posture of defense towards their neighbors (Slovaks, Hungarians, Poles, Ukrainians, and partly Czechs) who spoke different languages, and had different culture and partly different history. The worst time for Byzantine-rite Christians came in the second half the 20th century when the states where they lived were ruled by the Communists regimes which even banned the name "Rusyn" and refused to acknowledge that Rusyns represent a distinct group, or nationality. The Greek Catholic Church, as a symbol of the people, was liquidated in these states without any reference to nationality of its members. The complicated, possibly woeful history of the Byzantine-rite Christians in Central and Eastern Europe, including their elite - Brothers and Sisters who dedicated their life to Lord, is the reason for little general knowledge about Greek Catholic monasticism.
} 
PhDr. et Mgr. Jakub Zouhar, Ph.D.

University of Hradec Králové

Philosophical Faculty

Department of Auxiliary Historical Sciences and Archival Science

Náměstí Svobody 331

CZ-500 03 Hradec Králové

The Czech Republic

jakub.zouhar@uhk.cz 